Litteratur

1. Norske professorer fikk tobakks-penger. Verdens Gang 8.2.2002. www.vg.no/ nyheter/innenriks/norske-professorer-fikk.../a/1338398/ (6.7.2015).

2. Waldum HL, Nilsen OG, Nilsen T et al. Long-term effects of inhaled nicotine. Life Sci 1996; 58: 1339-46.

3. http://www.oecd.org/chemicalsafety/testing/goodlaboratorypracticeglp.htm (6.7.2015)

\section{Re: Hvordan leger ikke ønsker å dø}

Som pårørende vil jeg gjerne komme med noen kommentarer til artikkelen til Liv-Ellen Vangsnes om overbehandling i livets sluttfase (1). Min mor døde for noen år siden, 94 år gammel. Hun bodde på et eldresenter de siste årene, hvor hun hadde sin egen leilighet.

Dagen før hun døde spiste vi middag og kveldsmat sammen. Min mor døde på morgenen, etter at hun hadde fått hjelp til morgenstellet og frokost. Hun sovnet stille og rolig inn mens hun lå i sengen, da hun ønsket å hvile etter frokosten. Da personalet oppdaget at hun var død, opprettet de raskt kontakt med akutten. Ambulansen ble tilkalt, og ambulansepersonalet startet med intensiv gjenopplivning, med utstyr og slanger som dette medførte. Hun våknet ikke til liv igjen.

Min mor var, tross sin høye alder, «klar og tydelig i hodet» helt fram til det siste. Vi snakket gjerne om døden. Hun sa at hun var sliten i kroppen og hadde levd et langt og godt liv, og at hun nå ønsket å dø. Hun hadde sin kristne tro og snakket om sin egen avslutning på livet som en naturlig del av det å leve. Jeg som sønn ble ikke orientert av personalet på eldresenteret om at det ville bli igangsatt gjenopplivning. Noe jeg ville ha sagt nei til med henvisning til mine samtaler med min mor, og med respekt for hennes meninger.

I ettertid ser jeg det nesten som et overgrep på min mor at hun ikke fikk lov til å avslutte livet på en stille og rolig måte, og at andre mennesker besluttet at hun skulle forsøkes gjenopplivet mot hennes klare vilje. Jeg ser også at jeg (og mor) burde ha orientert personalet om hvordan hun ønsket å dø, men jeg trodde ikke at dette ville skje når hun var så gammel. Her mener jeg det burde være en rutine for at personalet har en samtale med den aktuelle og evt. pårørende om hvordan den enkelte ønsker å avslutte livet.

Jeg vil også legge til at da jeg kom til hennes leilighet etter hennes død, ble jeg av personalet nektet å komme inn i leiligheten. Begrunnelsen var at de ønsket å fjerne slanger og stelle henne før jeg fikk lov til å komme inn. Denne hendelen var faktisk det jeg opplevde som det mest ubehagelige og respektløse ved min mors død. Det virket på meg at personalet var mer redd for døden enn hva min mor og jeg var, både da hun levde og da hun var død.

\section{Erling Østberg}

e.ostberg@yahoo.no

Erling Østberg (f. 1954)

Ingen oppgitte interessekonflikter.

\section{Litteratur}

1. Vangsnes L-E. Hvordan leger ikke ønsker å dø. Tidsskr Nor Legeforen 2015; 135: 919.

\section{Re: $0 \mathrm{~m}$ å møte seg selv og andre i døren}

Takk for en ærlig og etterlengtet reaksjon på en særdeles ukritisk artikkel publisert i Tidsskriftet januar 2015. Frøisland tar i sine refleksjoner opp hvordan vi som leger kan ha godt av å møte oss selv i døren (1). Det er lett å kjenne seg igjen i hans beskrivelser. Vi jobber hver dag omringet av lidelse, tap og sorg. Vi møter mennesker i krise med behov for både empati og forståelse for den situasjonen de befinner seg i. Hvordan kan vi som leger være i stand til dette hvis vi ikke tåler svakheten i oss selv? Hvordan kan vi ha en genuin empati og forståelse for andres tilkortkommenhet, når vi ikke kan vedkjenne oss at vi alle kommer til kort?

Tid til selvrefleksjon er viktig. Vi har gått inn i et yrke hvor vi har mange «møter» i løpet av en uke; med pasienter, med pårørende og med kollegaer. Som Frøisland beskriver, er vi mennesker som har jobbet hardt for å være der vi er i dag. Og vi har fått bekreftelser på egenskapene vi innehar som har gjort det mulig å oppnå de målene vi har satt oss. Vi har fått bekreftelser på våre prestasjoner. Vi er flinke! Og det er bra! Det å være flinke og ressurssterke, som enkeltpersoner og som gruppe, må ikke stå i kontrast til å stoppe opp, trekke pusten, senke tempoet eller prioritere annerledes. Vi må være rause med oss selv og med våre kollegaer - $\mathrm{i}$ hverdagen, når livet blir mye, når vi ikke bare er mestrende, når vi blir små og når vi trenger å bli sett!

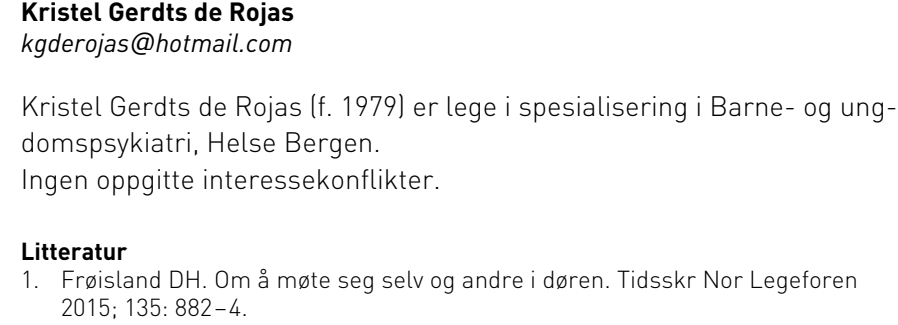

\section{RETTELSER}

\section{En entusiastisk altmuligmann}

Marit Tveito

Tidsskr Nor Legeforen 2015; 135: 846-8.

I intervjuet med Kjetil Søreide i Tidsskriftet nr. 9/2015 skal det i 1. Linje i 3. avsnitt på s. 846 stå: Han bor på Stokka i Stavanger... Og i det femte faktapunktet på s. 847 skal det stå: Professor ved Klinisk institutt 1 , Universitetet i Bergen, fra 2011

Vi beklager feilen, den er rettet på nett.

Legens venteværelse

Erlend Hem

Tidsskr Nor Legeforen 2015; 135: 1152-3

I Tidsskriftet nr. 12-13/2015 s. 1152 og 1153 sist i fotokrediteringene skal det stå: ( ) Kåre Kivijärvi/BONO 2015

Vi beklager feilen, den er rettet på nett. 